\title{
PROTECTION OF THE INTEREST OF WORKERS IN COURT PROCEEDINGS AFTER THE AMENDMENT TO THE POLISH CODE OF CIVIL PROCEDURE OF 4 JULY 2019
}

\begin{abstract}
The amendment of the Polish Code of Civil Procedure of 4 July 2019 (Dz.U. 2019, item 1469) introduced several changes to the Polish system of procedural law. In this light, the question arises, whether these changes significantly affect the status of workers who pursue their claims before labour courts. The subject of the paper is only the procedural aspect.
\end{abstract}

Słowa kluczowe: sąd pracy, postępowanie w sprawach z zakresu prawa pracy, sprawy z zakresu prawa pracy, status pracownika w sądzie

Keywords: labour court, labour court proceedings, labour law cases, employee rights

ASJC: 3308 , JEL: K31

The amendment of the Polish Code of Civil Procedure of 4 July 2019 (Dz.U. 2019, item 1469) introduced several important changes to the Polish system of procedural law starting from 7 November 2019. In this light, the question arises, whether these changes significantly affect the status of workers who pursue their claims before labour courts.

Mechanisms aimed at the protection of justified interest of workers in court proceedings have been present in the Polish procedural law system for decades. Their essence is to provide procedural assistance. As far as this issue is concerned, the provisions of Art. 5 of the Civil Procedure Code are essential. These provisions were not changed by the amendment of 4 July 2019, so the article remains unchanged and stipulates that in the event of justified need, the court may provide the necessary instructions concerning procedural actions to parties who appear in court without an attorney. The nature of this directive is facultative, which means that the court (also labour court) may decide about providing instructions at its own discretion, lege non distinquente. The main prerequisite for the court's actions under Art. 5 of the Civil Procedure Code is the existence of a justified need to take informative actions. The term "justified need" (the clause of "procedural necessity" was developed earlier by the judicature of the Supreme Court: 
the judgment of 13 May 1997, II UKN 100/97, OSNAPiUS 1998, No. 4, item 133; see also judgment of the Supreme Court of 9 September 2013, II PK 366/12, LEX 1573746) should be classified as an undefined term, being of a nature of a general clause. In the process of judicial application of the law, this allows to treat each case on an individual basis, adequately to the existing factual state. This type of legal construction allows the labour court each time to provide assistance to the party that actually needs such support, according to the court's evaluation of the circumstances of the case in question. Generally, this refers to cases where workers who appear in court without a professional attorney would be unable to influence the ongoing procedure and to exercise their rights (see the judgment of the Supreme Court of 30 June 1999, II UKN 21/99, OSNAPiUS 2000, No. 18).

Pursuant to Art. 5 of the Civil Procedure Code, the assistance of labour court is limited to the necessary instructions only. Thus, the provision does not oblige the court to provide the party with detailed instructions concerning all possibilities related to procedural actions. In this light, it seems justified to state that this provision is not applicable to the behaviour of the party while performing actions that are obviously understandable for everybody. This remark refers in particular to evidentiary proceedings. The initiative in this respect lies on part of the parties, whom the court is generally not obliged to instruct on the purpose of taking specific evidence (see the judgment of 9 February 2000, III CKN 590/98, LEX 52775).

However, the sole aim of the interpretation of Art. 5 of the Civil Procedure Code should not be to release the labour court from any obligations of an informative nature (Prusinowski 2013, pp. 26 ff). In this matter, I represent the view that the court should instruct the worker about the procedural claims that they are entitled to whenever there is a need justified by the circumstances of the case (see particularly the decision of the Supreme Court of 28 September 1999, II CKN 269/99, "Pracownik i Pracodawca" 2000, No. 2, item 27; the judgment of the Supreme Court of 11 October 2000, II UKN 33/00, OSNAPiUS 2002, No. 10, item 251; the judgment of the Administrative Court in Katowice of 22 April 2015, V ACa 726/14, LEX 1682851). Pursuant to the directive formulated in Art. 477 of the Civil Procedure Code in fine, the President of the court shall instruct the worker about the claims resulting from the referenced facts.

The instruction under Art. 5 taken together with art. 477 in fine of the Civil Procedure Code should be adequate to the specific factual situation of the worker that exists in the proceedings. If the instruction proves to be inaccurate or incorrect and the party has complied with it, then the party must not bear any negative consequences of this fact. Moreover, violation of the directive formulated in the discussed provision is a procedural defect that significantly affects the outcome of the case, provided that there was an existing justified need in concreto to provide the worker with procedural guidelines. An example illustrating this type of situation is the failure to inform the worker about the possibility to file a motion to appoint a public defender.

Art. 5 of the Civil Procedure Code realises the directive vigilantibus iura scripta sunt. The adopted normative formula introduces an element of flexibility to legal assistance, 
which is necessary also in labour law cases. On the other hand, in the functional aspect it helps eliminate the detrimental phenomenon in procedural relations, being the passive attitude of the party to the proceedings, manifested by waiting passively for the official actions of the court. It should be emphasised here (see decision of the Supreme Court of 15 October 2014, I PZ 20/14, LEX 1541251) that the violation of Art. 5 of the Civil Procedure Code does not result in the invalidity of the proceedings, as it does not deprive the party of the possibility to defend their rights, although it may qualify as a violation of procedural provisions.

However, the protection of workers' interests in Polish procedural labour law is mainly manifested in the fact that the labour court performs procedural actions ex of ficio, so to say, in the worker's place. Such actions may be performed at various stages of the proceedings-either during the proceedings concerning the essence of the case (e.g. appointing a legal guardian-Art. $460 \$ 2$ of the Civil Procedure Code), or during the settlement phase (e.g. considering alternative claims-Art. 4771 of the Civil Procedure Code, granting an order of immediate enforceability-Art. $4772 \S 1$ of the Civil Procedure Code). The systematics presented above will provide a starting point for a further analysis of the "judicial paternalism" aimed at protecting the interests of workers in labour law proceedings. These mechanisms also remained unchanged by the amendment to the Code of Civil Procedure of 4 July 2019.

Let me begin the considerations of this issue by characterising the forms of support included in the first category and stipulated in the provisions of Art. $460 \$ 2$ and art. 477 of the Civil Procedure Code. The first of the quoted provisions may constitute a classic example of an obligation to act ex officio in the interest of the worker that is imposed on the court. In other forms of proceedings in civil cases (sensu largo), a custodian may be established for a party devoid of procedural capability, who does not have a statutory representative, as well as for a party that does not have an organ authorised to represent it only upon the motion of the opposing party. However, in labour law cases, this initiative is also vested in the labour court, which may appoint a guardian ex officio, if necessary (Machnikowska 2016, p. 486). Accepting such wording of the provisions of Art. 460 of the Civil Procedure Code (of which I do approve), means that the legislatory authority left the question, when such justified need arises in reference to a specific case, at the discretion of the court.

A legal mechanism that is identical to Art. 460 of the Civil Procedure Code in its essence, also functions under Art. 477 of the Civil Procedure Code. This provision stipulates that in proceedings initiated on petition filed by the worker (it is worth emphasising here that in labour law cases, in which the worker is the defendant, the summons to join the proceedings is governed by general regulations; see Art. 194 of the Civil Procedure Code), the court may ex officio summons the entities specified in Art. 194 $\$ 1$ and 3 of the Civil Procedure Code to take part in the proceedings (Machnikowska 2016, pp. $492 \mathrm{ff}$ and literature quoted therein). This applies to situations when the petition was not filed against a person (the function of this regulation is to remedy the lack of passive entitlement to act during the proceedings), who should be the defendant 
in the case or situations, where petitions referring to the same claim may also be filed against other persons who do not take part in the case as defendants.

The analysis of the wording of Art. 477 of the Civil Procedure Code leads to the conclusion that the legislatory authority has granted the labour court a rather wide scope of discretion with respect to summoning parties to take part in the case ex officio, because no specific prerequisites that would oblige the court to do so were formulated. Expressis verbis, even the protection of the worker's interest does not constitute such prerequisite (see the judgment of the Supreme Court of 24 June 2015, II PK 182/14, LEX 1766114; the decision of the Supreme Court of 22 July 2014, III PZ 7/14, LEX 1498820), although one should bear in mind that it is, in fact, an inherent element of the form of the court's actions in cases initiated by the workers. The wording of Art. 477 of the Civil Procedure Code thus enables the court to adjust its decisions in a flexible way and to adapt them to the circumstances of the given case. I do not have any doubts that the court plays a subsidiary function in that matter, meaning that it makes the relevant decision ex official only if the worker fails to file the required motion in spite of being instructed to do so.

In the further section of my considerations I would like to reflect on the actions performed ex officio by labour courts in order to protect the vital interests of the worker at the stage of issuing judgment. This refers to such actions as considering an alternative claim (Art. 4771 of the Civil Procedure Code) or issuing an order of immediate enforceability of the sentence (Art. 4772 and 4776 of the Civil Procedure Code). In the cases specified herein, there are significant differences between the provisions that regulate these instruments in labour law proceedings and those that regulate these issues in proceedings in other categories of civil law cases.

An instrument of special protection of the worker's interest is the possibility to consider an alternative claim by the court (see the judgment of the Supreme Court of 10 March 2010, II PK 266/09, LEX 602245; the judgment of the Supreme Court of 3 September 2009, III PK 33/09, OSNP 2011, No. 9-10, item 120, thesis 2; judgment of 23 July 2009, II PK 26/09, LEX 533037, thesis 1; judgment of the Supreme Court of 16 January 2009, I PK 138/08, OSNP 2010, No. 15-16, item 184), if the claim chosen by the worker has proven to be unjustified. The directive provided for in Art. 477(1) of the Civil Procedure Code refers to situations, when the worker is entitled to at least two claims (see the judgment of the Supreme Court of 14 October 2014, II PK 293/13, LEX 1545143, thesis 1), connected in such a way that the fulfilment of only one of them is sufficient for the fulfilment of the employer's obligations (e.g. claim for reemployment or compensation). The worker may choose the specific claim, which may be either based on the contract or statutory, at their own discretion. However, if the worker chose the wrong claim, then, without Art. 4771 of the Civil Procedure Code, their claim would be rejected by the court and the worker would not receive any consideration, which would doubtlessly be detrimental to their interest.

The main issue that arises from the interpretation of the provisions of Art. 4771 of the Civil Procedure Code is the question, whether the consideration of an alternative claim by the labour court is obligatory or facultative. If we analyze the problem only in 
literary terms, it is difficult to assume that an absolute obligation to consider alternative claims has been imposed on the court, as the provision stipulates that "the court may consider a different, alternative claim ex officio" (see the judgment of the Supreme Court of 2 December 2012, II PK 131/10, LEX 794786). Personally, however, I represent the standpoint that purposes of pertinence, in particular the necessity to protect the justified interests of the worker, support the need to assume an interpretation that is different from the letter of the law. Thus, I suggest that it should be assumed that considering an alternative claim is not at the discretion of the court, but that the court is obliged to do so, if the circumstances of the given case require it.

The procedural action that is performed by the court in the stage of issuing judgment and contributes directly to the protection of worker's interest is making the decision enforceable immediately. The first and foremost of all standards that regulate this issue in labour law cases is Art. $4772 \S 1$ of the Civil Procedure Code, which stipulates that, when adjudging compensation to the worker in this type of cases, the court shall make the judgment enforceable immediately ex officio, with respect to the part not exceeding one full monthly remuneration. The wording of Art. $4772 \$ 1$ of the Civil Procedure Code quoted herein shows clearly that the court is obliged to issue the order of immediate enforcement. This is confirmed by the use of the phrase "shall make." Such an explicit wording does not leave the labour court any room for maneuver.

The provisions of Art. $4772 \$ 1$ of the Civil Procedure Code give rise to the issue of the scope of this obligation (Góra-Błaszczykowska 2016, p. 699). In my opinion, it has two essential aspects: the first is the type of judgments in labour law cases that are made enforceable immediately, and the second one-the "dimension" of such order of immediate enforcement. Let me start the analysis of the problem from the first of these aspects. The starting point will be the assumption that in labour law cases, similarly as in other types of civil law cases sensu largo, only those judgments that may be enforced are assigned an order of immediate enforcement. This means that this does not apply to constitutive judgments in general and such declarative judgments that do or do not establish the existence of a legal relationship or right, as all of them are "self-enforceable" by nature. Thus, only declarative judgments that order the defendant to make a certain consideration ${ }^{1}$ will remain in the area of our interest. As in Art. $4772 \$ 1$ of the Civil Procedure Code the legislatory authority uses the term "amount due" which, de lege lata, may refer only to financial means, I am justified to state that the scope of this provision includes only judgments adjudging financial considerations. This interpretation concept is confirmed indirectly in the further part of the discussed standard, where the scope of the order of immediate enforcement has been defined as "one month remuneration."

${ }^{1}$ In the light of the lege non distinquente argument the view of the Supreme Court expressed in the resolution of 6 March 1986, III PZP 11/86 (OSNCP 1987, No. 1, item 11) that the obligation to make the judgment immediately enforceable ex officio under Art. $4772 \S 1$ of the Civil Procedure Code does not apply to remuneration adjudged conditionally to the worker in the judgment on re-employment, seems disputable. 
The upper limit of the scope is thus the full monthly remuneration of the worker. This interpretation is based on the literal wording of Art. $4772 \S 1$ of the Civil Procedure Code, specifically on the phrase stating that the court shall make the part of the judgment not exceeding one full monthly remuneration immediately enforceable. In practice, this means that, if an amount of compensation lower than one full monthly remuneration is adjudged in a labour law case, then the order of immediate enforcement should be assigned to the whole judgment. The amendment of the Code of 4 July 2019, modified Art. $4772 \$ 2$ thereof. The revised version of the provision states that the labour court that deems the termination of an employment contract ineffective or orders re-employment of the worker may order the employer to continue to employ the worker until the court proceedings are closed effectively. In comparison to the old version, the amended wording of this provision is much more beneficial for the interest of the workers. This is due to the fact that the obligation to continue employment of the worker refers not only to termination of the employment contract upon notice, as it was previously, but also to termination without notice. This view is supported by argumentation lege non distinquente. As a result, the objective scope of the protection with respect of the claims has become significantly more beneficial.

Another instrument protecting the interests of the worker is also the extended mechanism of presenting evidence foreseen in Art. 473 of the Code of Civil Procedure. By introducing Art. $473 \$ 1$ of the Code, the legislatory authority has implicitly eliminated the superiority of documentary evidence (Piasecki 1965, pp. $32 \mathrm{ff}$ ) and thus significantly expanded the possibilities to determine objective truth. In a way, the amendment also removed the loophole in the Labour Code connected with the issue of invalidity of the employment contract and the problem of so-called factual employment relationships.

A procedural mechanism that has been introduced by the amendment to the Code of Civil Procedure of 4 July 2019, is the preparatory session (Art. 2055-2059 of the amended Code). In principle, it should accelerate the consideration of the case in the first instance, which is usually in the interest of the worker. Pursuant to Art. $2055 \$ 1$ of the Civil Procedure Code, the aim of such session is to resolve the dispute without conducting a hearing. Parties and their attorneys are obliged to take part in the session. The labour court may release the worker from the obligation to appear at the preparatory session if the circumstances of the case demonstrate that the participation of their attorney will be sufficient.

During the preparatory session, the judge determines the subject of the dispute with the parties and clarifies their position with respect to that matter (see Art. $2056 \$ 1$ of the Civil Procedure Code). The court should also strive to settle the case in an amicable manner, by formulating settlement proposals and indicating methods to resolve the dispute.

Another legal instrument protecting the interests of the worker is the alternating jurisdiction of the court, which was changed by the Act of 4 July 2019. De lege lata a worker may file a petition in a labour law case either to the competent court of general jurisdiction for the defendant (i.e. the employer) or to the court, in whose jurisdiction the work was or was to be performed. In practice, this means that it is usually the place of 
performing work that determines the competent court in labour law cases. However, this regulation does not constitute an improvement to the previously binding version of Art. $461 \S 1$ of the Civil Procedure Code.

A further procedural mechanism that protects the worker's interest is the possibility for the trade union to file a petition on behalf of the worker, foreseen in Art. 462 $\$ 1$ of the Civil Procedure Code. When initiating the proceedings, trade union is formally entitled to bring the action to court and becomes a party to the proceedings. The court notifies the worker on whose behalf the petition was filed by delivering a copy of the petition. Then, the worker may join the proceedings at any stage. If they fail to do so, the trade union will act independently in the proceedings, although it must not dispose freely of the subject of the dispute (e.g. waive the claim or conclude a settlement agreement). It is also worth noting that, when filing a petition on behalf of the worker, the trade union cannot demand to determine the legal relationship or right concerning the union and it cannot refer to its own legal interest in determining the above, e.g. demand the court to determine that the employer has violated a binding legal regulation.

Petition on behalf of the worker may also be filed by a labour inspector (Iwulski 1998, pp. $25 \mathrm{ff}$ ). Pursuant to Art. 631 of the Code of Civil Procedure, the inspector has the right to initiate court proceedings in claims for determining the existence of an employment relationship. In practice, this refers to the situations when work was or is performed in the conditions characteristic for an employment relationship, i.e. for the employer and under the employer's direction at a place and time specified by the employer (Art. 22 of the Labour Code). In the light of the jurisdiction of the Supreme Court (the judgment of 11 April 1997, I PKN 89/97, OSNAPUS 1998, No. 2, item 35), the lack of obligation to follow orders is an argument against the possibility to consider a legal relationship as an employment relationship.

The court notifies the worker on whose behalf the petition was filed by the labour inspector by delivering a copy of the petition. Then, the worker may join the proceedings at any stage, acting as the petitioner (Art. 631 of the Civil Procedure Code).

The various mechanisms protecting the worker's interests by the labour court discussed above lead to some ambivalent reflections. Each of these mechanisms, if considered separately, deserves praise, as it directly contributes to the protection of workers' interests. However, a comprehensive analysis of all these mechanisms raises fears whether the labour court has not been deprived of its position of an objective arbiter to become an actual advocate of the worker. The paternalistic element, which is very strongly manifested in Polish procedural civil law, especially at the stage of issuing judgments, raises anxiety concerning the principle of equality of parties to the proceedings. Thus, in my personal opinion, my acceptance of the supportive function of the court is limited to the phase of preparing the case for settlement. On the other hand, at the stage of issuing judgment, the role of a "caretaker" should recede into the background and be limited only to these situations, when the worker is unable to take due care of their interests as a result of circumstances beyond their control. By no means 
should the court however be the agent that strives to ensure the most beneficial outcome of the case for the worker, contrary to the principle of objectivity.

The amendment to the Code of Civil Procedure of 4 July 2019 did not introduce any qualitative changes to the protection of workers' interests in labour law cases. Only the mechanism foreseen in Art. $4772 \$ 2$ of the Code, which permits to oblige the employer to continue employment of the worker until the court proceedings are lawfully closed, is a significant change in the legal status of parties to the proceedings. Unfortunately, it is currently impossible to predict, whether this will contribute to a significant improvement in the position of workers in industrial relationships.

\section{References}

Flejszar R. (2012) Ograniczenie zasady dyspozycyjności w postępowaniu w sprawach z zakresu prawa pracy, "Studia z Zakresu Prawa Pracy i Polityki Społecznej."

Góra-Błaszczykowska A. (2016) [in:] K. W. Baran (red.), System prawa pracy, t. 6: Procesowe prawo pracy, Warszawa.

Iwulski J. (1998) Udzial inspektora pracy w postępowaniu o ustalenie istnienia stosunku pracy, "Praca i Zabezpieczenie Społeczne," nr 9.

Machnikowska A. (2016) [in:] K. W. Baran (red.), System prawa pracy, t. 6: Procesowe prawo pracy, Warszawa.

Piasecki K. (1965), Problematyka formy czynności prawnych i dowodów z dokumentów w zakresie stosunków pracy, "Palestra," nr 10.

Prusinowski P. (2013) System dyskrecjonalnej władzy sędziego w sprawach z powództwa pracownika, "Praca i Zabezpieczenie Społeczne," nr 1.

\section{Court sentences}

The resolution of the Supreme Court of 6 March 1986, III PZP 11/86, OSNCP 1987, No. 1, item 11. The judgment of the Supreme Court of 11 April 1997, I PKN 89/97, OSNAPUS 1998, No. 2, item 35 .

The judgment of the Supreme Court of 13 May 1997, II UKN100/97, OSNAPiUS 1998, No. 4, item 133.

The judgment of the Supreme Court of 30 June 1999, II UKN 21/99, OSNAPiUS 2000, No. 18. The decision of the Supreme Court of 28 September 1999, II CKN 269/99, "Pracownik i Pracodawca" 2000, No. 2, item 27.

The judgment of the Supreme Court of 9 February 2000, III CKN 590/98, LEX 52775.

The judgment of the Supreme Court of 11 October 2000, II UKN 33/00, OSNAPiUS 2002, No. 10, item 251.

The judgment of the Supreme Court of 16 January 2009, I PK 138/08, OSNP 2010, No. 15-16, item 184.

The judgment of the Supreme Court of 23 July 2009, II PK 26/09, LEX 533037. 
The judgment of the Supreme Court of 3 September 2009, III PK 33/09, OSNP 2011, No. 9-10, item 120.

The judgment of the Supreme Court of 10 March 2010, II PK 266/09, LEX 602245.

The judgment of the Supreme Court of 2 December 2012, II PK 131/10, LEX 794786.

The judgment of the Supreme Court of 9 September 2013, II PK 366/12, LEX 1573746.

The decision of the Supreme Court of 22 July 2014, III PZ 7/14, LEX 149882.

The judgment of the Supreme Court of 14 October 2014, II PK 293/13, LEX 1545143.

The decision of the Supreme Court of 15 October 2014, I PZ 20/14, LEX 1541251.

The judgment of the Administrative Court in Katowice of 22 April 2015, V ACa 726/14, LEX 1682851.

The judgment of the Supreme Court of 24 June 2015, II PK 182/14, LEX 1766114.

\section{Legal acts}

The Code of Civil Procedure of 4 July 2019, Dz.U. 2019, item 1469. 